\title{
Tiger density in a tropical lowland forest in the Eastern Himalayan Mountains
}

\author{
Randeep Singh ${ }^{{ }^{*}}$, Devendra Singh Chauhan ${ }^{1}$, Sudhanshu Mishra', Paul R Krausman² and Surendra Prakash Goyal ${ }^{1}$
}

\begin{abstract}
Tropical evergreen forests in northeast India are a biological hot spot for conservation of flora and fauna. Little is known, however, about tiger abundance, which is a flagship species for tropical evergreen forests. Our objective was to document the capture rate and population density of tigers based on spatial explicit capture-recapture (SECR) approaches using camera trap data in an intensive study area (ISA) of $158 \mathrm{~km}^{2}$ in Pakke Tiger Reserve (PTR) during March to May 2006. The Reserve lies in the foothills of the Eastern Himalayan Mountains, northeast India. We monitored 38 camera traps in ISA for 70 days and documented 10 photo-captures of tigers ( 5 left and 5 right flanks) with an average trap success rate of 1.3 captures/100 trap days. The overall capture probability was 0.05 . The tiger density estimated using a SECR model was $0.97 \pm 0.23$ individuals $/ 100 \mathrm{~km}^{2}$. This is the first systematic sampling study in tropical semi evergreen forests of India, and information on capture rate and population density of tigers provides baseline data from which to determining changes in the future to assist conservation.
\end{abstract}

Keywords: Camera-trap; Northeast India; Panthera tigris; SECR; Semi-evergreen

\section{Introduction}

It is important to have information on distribution, abundance, and trends for making effective conservation and management planning and policies of large carnivores occurring naturally at low densities (Nowell and Jackson 1996). Among the large carnivores, tiger (Panthera tigris) is a flagship species in many of the eco-regions of Asia. Habitat loss, prey depletion, forest fragmentation, poaching, skin trade, and retaliatory killing are the interrelated impacts responsible for decline in tiger populations across its range (Dinerstein et al. 2007). It is crucial to monitor and assess abundance and status of such vulnerable species targeted by hunters, to identify problems, so that remedial steps can be initiated, otherwise local extinction of such species may occur (Barber-Meyer 2010), even in protected areas (Reddy 2008).

Tropical semi-evergreen rain forests in Southeast Asia are hot spots of biodiversity, and the eastern Himalayan region, especially northeast India, has been identified as one of the most biodiverse regions of the world (Myers et al. 2000). Tigers naturally occurs in low densities in

\footnotetext{
* Correspondence: randeep04@rediffmail.com

'Wildlife Institute of India, Post Box \# 18, Dehradun, Uttarakhand 248001 , India

Full list of author information is available at the end of the article
}

tropical rainforests and are difficult to detect (Lynam et al. 2009). The utility of remotely triggered cameratraps offer possibilities with elusive species to generate photographic evidence to estimate the abundance and density in which individual identification is possible from the coat pattern (i.e., tiger Panthera tigris; Karanth and Nichols 1998; Ramesh et al. 2012; Singh et al. 2013a; 2013b; 2014a).

Presently very little is known regarding the abundance and population density of tigers from the tropical semievergreen forest of northeast India. Our objective was to provide, baseline information on the capture rate and population density of tigers in Pakke Tiger Reserve (PTR), Arunachal Pradesh, India. The PTR is one of four designated tiger reserves in northeast India, where illegal hunting and logging are serious threats for the conservation of the species.

\section{Material and methods \\ Study site \\ Pakke Tiger Reserve $\left(862 \mathrm{~km}^{2}, 26^{\circ} 54^{\prime}-27^{\circ} 16^{\prime} \mathrm{N}\right.$, and $92^{\circ} 36^{\prime}-93^{\circ} 09^{\prime} \mathrm{E}$ ) lies in the foothills of the Eastern Himalaya in the East Kameng District of Arunachal Pradesh (Figure 1) bordering Assam. It was declared a sanctuary in 1977, and has been recently declared a}




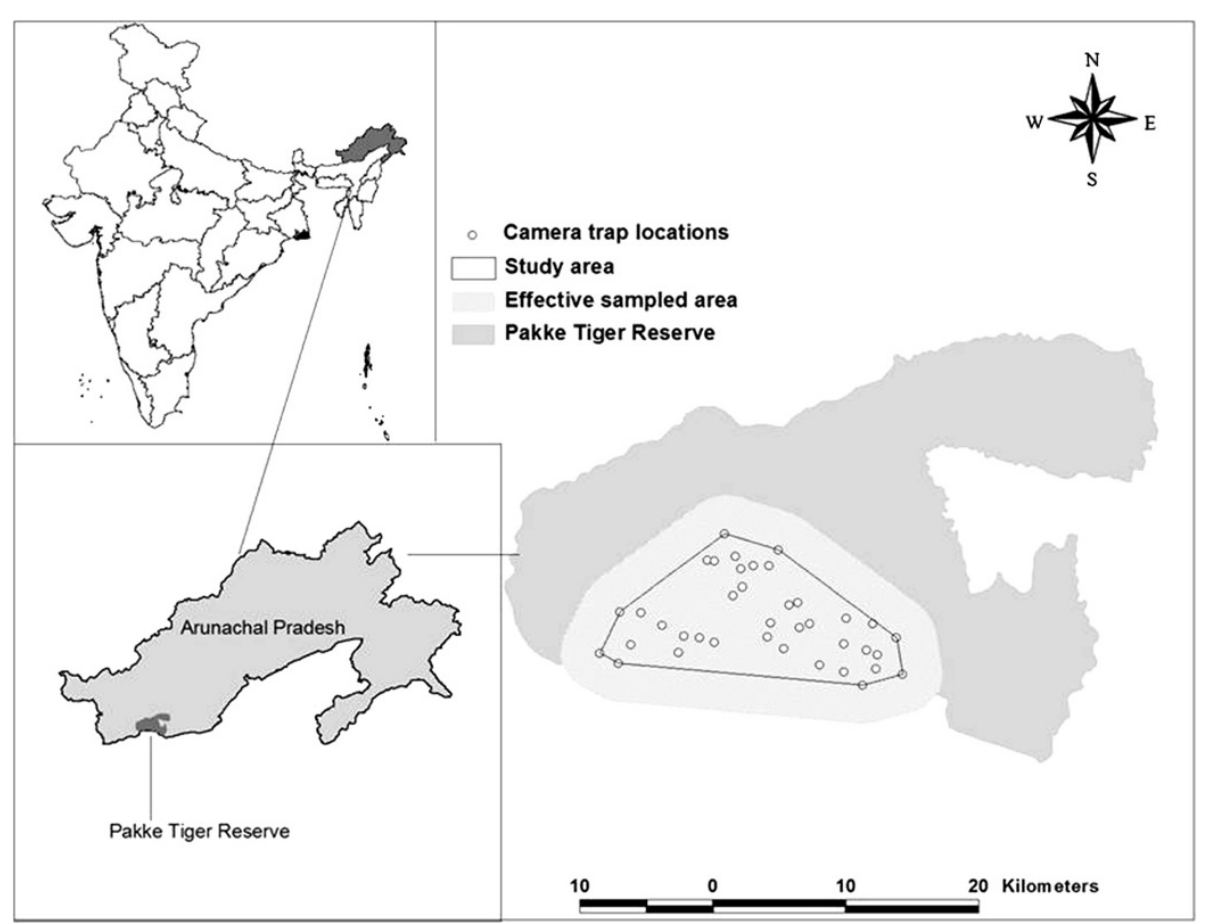

Figure 1 Location of the intensive study area in Pakke Tiger Reserve in Arunachal Pradesh, India, with effectively sampled area and camera trap locations.

tiger reserve. The park is surrounded by contiguous forests on most sides and bounded by rivers in the east, west, and north. The terrain is undulating and hilly, with elevations from 150 to $2,000 \mathrm{~m}$ above sea level. At least 60 mammal species are reported from the park, including 7-8 species of felids, one bear, and two canid species, 16 viverrids, mustelids and herpestids, seven large herbivores, and four primate species (Datta and Goyal 1997). The vegetation of the park is classified as Assam valley tropical evergreen forest (Champion and Seth 1968). More than 20 villages and small settlements are located near the south-eastern boundary of the park adjacent to the Pakke River with an adult population of about 4,000 people (Datta and Goyal 1997). The area has great biological significance due to the richness of its flora and fauna, a result of its location in the Oriental and the Indo-Malayan realm, and has been considered as a hot spot for biodiversity (Myers et al. 2000).

\section{Sampling and analysis}

Because of mountainous terrain and lack of an adequate road network, an intensive reconnaissance survey in dry stream beds, as suggested by Johnsingh et al. (2004), was conducted to record tracks and signs of large carnivores, especially tigers. Based on the distribution pattern of tracks, we identified an intensive study area (ISA) of $158 \mathrm{~km}^{2}$ in the PTR with minimal human disturbance. We selected 38 camera-trap locations based on the presence of tiger sign (i.e., tracks, scat, scrap marks). We conducted camera trapping, with active infrared camera-traps and13 TrailMaster TM 1550 plus camera kits (Goodson and Associates, Lenexa, Kansas, USA) between March and May 2006. Due to limited cameratraps, resource constraints, and lack of adequate roads for regular monitoring of cameras, we identified three trapping blocks (spatially separated) within the ISA and the cameras were deployed in a phased manner to systematically sample the area under "survey design 4" (Figure 1, Karanth and Nichols 2002). All camera-traps were operational for 24 hours. Each camera-trap location had single camera-traps positioned on either side of a trail. Combined captures from 1 day drawn from each block were used for each sampling occasion (Otis et al. 1978). To reduce the likelihood of tigers moving in and out of the trapping area undetected, we used a minimum trap spacing of $0.8 \mathrm{~km}$ and a maximum trap spacing of $2.2 \mathrm{~km}$ without any large holes in the sampling area (Karanth and Nichols 2002). We used the time and day imprinted in photo-capture to construct the capture matrix of individual tigers (Karanth and Nichols 2002). We tested the population closure assumption by using program CAPTURE (Rexstad and Burnham 1991). We constructed a capture history of tiger in spatial explicit capture-recapture (SECR) data format for analysis that considered a continuous 70-day sampling occasion (Singh et al. 2014b). We followed 
the SECR approach to obtain maximum likelihood density estimates for tigers using the camera trapping data (Efford 2011; Royle et al. 2009; Gopalaswamy et al. 2012).

We implemented the likelihood SECR models in program DENSITY 5.0 (Efford 2008; www.otago.ac.nz/density). We modeled the detection probability of each individual using the spatial detection function (Efford 2004), which was explained by two parameters (one-night detection probability at the center of an individual's home-range, $\left[\mathrm{g}_{\mathrm{o}}\right]$ and a function of the scale of animal movements [б]; Efford 2004). We used a half-normal detection function because it is appropriate for markrecapture data from large carnivores. We evaluated the log likelihood function by integrating the Poisson distribution of the home range centers by adding a buffer of $10,000 \mathrm{~m}$ around the trapping grids (this distance was chosen to ensure that no individual outside of the buffered regions had any probability of being photographed by the camera trap during the survey; Zimmermann et al. 2013). The mean maximum distance moved was calculated using 1 recapture only. During our study one tiger recapture approximates a distance of $11 \mathrm{~km}$, thus we used this distance to compute MMDM. For comparison we estimated tiger density using half the mean maximum distance moved ( $1 / 2 \mathrm{MMDM}$ ) approach (Karanth and Nichols 1998).

\section{Results}

During the sampling period a sampling effort of 718 trap days over $158 \mathrm{~km}^{2}$, documented 10 tiger photographs ( 5 left flank photographs belonging to 4 individuals and 5 right flank photographs of 3 individuals) with a capture rate of 1.3 captures/100 trap days or 1 tiger every 71.8 trap-nights. Because there were more photo-captures of left flanks we used those data for density estimates. The statistical test for population closure in CAPTURE (Rexstad and Burnham 1991) supported the assumption that the sampled population was closed for the study period $(z=51.339, P=0.09027)$. Using the $M_{h}$ jackknife estimator the capture probability (p-ht) was estimated as 0.05 . The maximum distance moved was $0.97-11.88 \mathrm{~km}$ and the $1 / 2 \mathrm{MMDM}$ was $2.96 \mathrm{~km}$. The boundary buffer width (W) was $2.96 \mathrm{~km}$ and the effectively sampled area (W) was $347 \mathrm{~km}^{2}$, thus the tiger estimated density (D [S.E]) was $1.15 \pm 0.80$ adult tigers/ $100 \mathrm{~km}^{2}$. The maximum likelihood (ML) tiger density was estimated as $0.97 \pm 0.23$ individuals $/ 100 \mathrm{~km}^{2}$. The detection probability at the home range center $\left(\mathrm{g}_{0}\right)$ was estimated at $0.0009 \pm 0.0001$. The sigma (a function of movement) value was $3,253 \mathrm{~m} \pm 462 \mathrm{~m}$.

\section{Discussion}

Through, tropical semi-evergreen dense forests of Southeast Asia are well known as hot spots in biodiversity, they are considered to be poor habitat for prey, and thus vary in their density of carnivores (Datta et al. 2008). In protected areas of tropical rain forests of northeast India, carnivores are rare (Karanth and Nichols 2000; Datta et al. 2008). At Namdapha Tiger Reserve in tropical ever green forest, northeastern India, camera traps failed to detect any photo-captures of tigers after 451 (Karanth and Nichols 2000) and 1,537 trap days (Datta et al. 2008), even though tiger's were known to be present. Similar results were obtained in Protected Areas (PA) in northern and central Thailand; only a single tiger was detected in each survey (Lynam et al. 2001, 2006). Thus, most of the studies so far undertaken in tropical rainforests of Southeast Asia have documented low rates of capture (0.03 to 2.7) of tigers in comparison to other areas (Table 1). During our study we recorded 10 photo-captures of tigers after 70 days of sampling (1.3 capture/100 trap days). Similar in northern Myanmar, after 190 day of sampling only 12 captures of 6 tigers were recorded in 3 different protected areas (Lynam et al. 2009). In PTR, tigers were detected with very low encounter rates in camera-traps but they were captured evenly in all trapping areas, which indicate the species' presence throughout PTR in low densities.

The capture probability estimate in our study area is low (0.05), but also higher than minimal capture probability $(0.03)$ required achieving reliable population density estimate (Harmsen, 2006). In a few areas of tropical semievergreen forests such as Gunung Leuser (GL) and Bukit Barisan Selatan, (BBS) of Indonesia, the capture probability (p-ht) remained very low (0.05) in spite of the very high number of camera trap days $(2,686$ to 4,064 trap days, respectively) (Figure 2). Thus, low capture probability should be expected in tropical rain forests because of low population densities of tiger.

Our results showed that the densities estimated under spatial $(0.97 \pm 0.23)$ and non-spatial approach $(1 / 2 \mathrm{MMDM}$; $1.15 \pm 0.80)$ were almost similar. The results of density estimates $\left(0.97 \pm 0.23\right.$ adult tigers $\left./ 100 \mathrm{~km}^{2}\right)$ in PTR supports the fact that tigers occurs at low densities in tropical rain forests as reported in other rainforests (Table 1).

The reported population densities of tiger in tropical rain forest has been reported to range from $0.21-2.95$ tiger $/ 100 \mathrm{~km}^{2}$, while in tropical dry and moist deciduous forest and grassland habitats the population densities of tiger were reported from 4 to 16 individuals per $100 \mathrm{~km}^{2}$ (Carbone et al. 2001; Karanth et al. 2004; Jhala et al. 2011). The variation in results between sites may be because of differences in vegetation, prey availability, and hunting pressure (Chapron et al. 2008). The tropical rainforests offer little primary productivity at ground level, and thus, the mammalian biomass is dominated by arboreal herbivores (Eisenberg 1980). A high proportion 
Table 1 Comparison of tiger captures rate and density derived from camera traps in Pakke Tiger Reserve, India and other tropical rain forest in Southeast Asia

\begin{tabular}{|c|c|c|c|c|c|c|c|c|}
\hline Location & Code & Country & $\begin{array}{l}\text { Total } \\
\text { camera } \\
\text { days }\end{array}$ & $\begin{array}{l}\text { Total no. } \\
\text { photos }\end{array}$ & $\begin{array}{l}\text { Total no. } \\
\text { tigers }\end{array}$ & $\begin{array}{l}\text { Effective sampled } \\
\text { area }\left(\mathrm{km}^{2}\right)\end{array}$ & $\begin{array}{l}\text { Tiger density } \\
\left(\text { no. } / 100 \mathrm{~km}^{2}\right)\end{array}$ & $\begin{array}{l}\text { Capture/100 } \\
\text { trap days }\end{array}$ \\
\hline Pakke Tiger Reserve (Present study) & PTR & India & 748 & 10 & 4 & 347 & 1.15 & 1.3 \\
\hline Namdapha Tiger Reserve (Datta et al. 2008) & NTR & India & 1537 & 0 & 0 & 1200 & 0 & 0 \\
\hline Gunung Leuser $^{a}$ & $\mathrm{GL}$ & Indonesia & 2686 & 45 & 10 & 550 & 1.82 & 1.7 \\
\hline Bukit Barisan Selatan $^{\mathrm{a}}$ & BBS & Indonesia & 4064 & 19 & 9 & 836 & 1.08 & 0.5 \\
\hline Kerinchi Seblat ${ }^{a}$ & KS & Indonesia & 5316 & 62 & 16 & 800 & 2.00 & 1.2 \\
\hline Halabala WS, Narathiwa Province ${ }^{a}$ & HWS & Thailand & 999 & 9 & 2 & 166.7 & 1.20 & 0.9 \\
\hline Queen Sirikit Reserve Forest, Yala Province ${ }^{a}$ & QSR & Thailand & 683 & 17 & 3 & 166.7 & 1.80 & 2.5 \\
\hline Phu Khieo WS, Chaiyaphum Province ${ }^{a}$ & PKWS & Thailand & 989 & 3 & 1 & 86.2 & 1.16 & 0.3 \\
\hline Khao Yai NP, Nakhon Ratchasima Province ${ }^{a}$ & KYNP & Thailand & 647 & 2 & 1 & 83.3 & 1.20 & 0.3 \\
\hline Temenggor Forest Reserve, Perak ${ }^{\mathrm{a}}$ & TFR & Malaysia & 812 & 8 & 2 & 86.2 & 0.32 & 1.0 \\
\hline Bintang Hijau Forest, Perak $^{\mathrm{a}}$ & BHF & Malaysia & 776 & 7 & 2 & 202 & 0.99 & 1.0 \\
\hline Gunung Tebu Forest Reserve, Terngganu ${ }^{a}$ & GTF & Malaysia & 807 & 12 & 1 & 188.7 & 0.53 & 1.5 \\
\hline Ulu Temaing Forest Reserve, Kelantan ${ }^{a}$ & UTF & Malaysia & 563 & 15 & 2 & 210.5 & 0.95 & 2.7 \\
\hline Taman Negara ${ }^{a}$ & $\mathrm{TN}$ & Malaysia & 1829 & 6 & 4 & 338.2 & 1.18 & 0.3 \\
\hline Bungo primary selectively logged forest ${ }^{b}$ & $\mathrm{BP}$ & Sumatra & 2750 & 63 & 10 & 441 & 2.95 & 2.3 \\
\hline Ipuh primary selectively logged forest ${ }^{b}$ & IP & Sumatra & 3255 & 64 & 15 & 1227 & 1.55 & 2.0 \\
\hline Gunung Basor Forest Reserve ${ }^{a}$ & GBFR & Malaysia & 2496 & 18 & 6 & 308 & 2.59 & 0.7 \\
\hline
\end{tabular}

${ }^{a}$ Carbone et al. 2001.

binkie et al. 2008.

of the primary productivity in rain forests is in the canopy and is available to relatively small mammals, so food availability for large ungulates in tropical forests is low, hence low density of ungulates is expected (Glanz 1982). Because tiger abundance is related to prey abundance
(Sunquist et al. 1999; Karanth et al. 2004), a lower tiger population density is likely in tropical rain forests.

Enforcement of India's laws that entirely prohibit hunting of all wildlife is a challenge, especially in northeast India, where local tribes have a strong tradition of

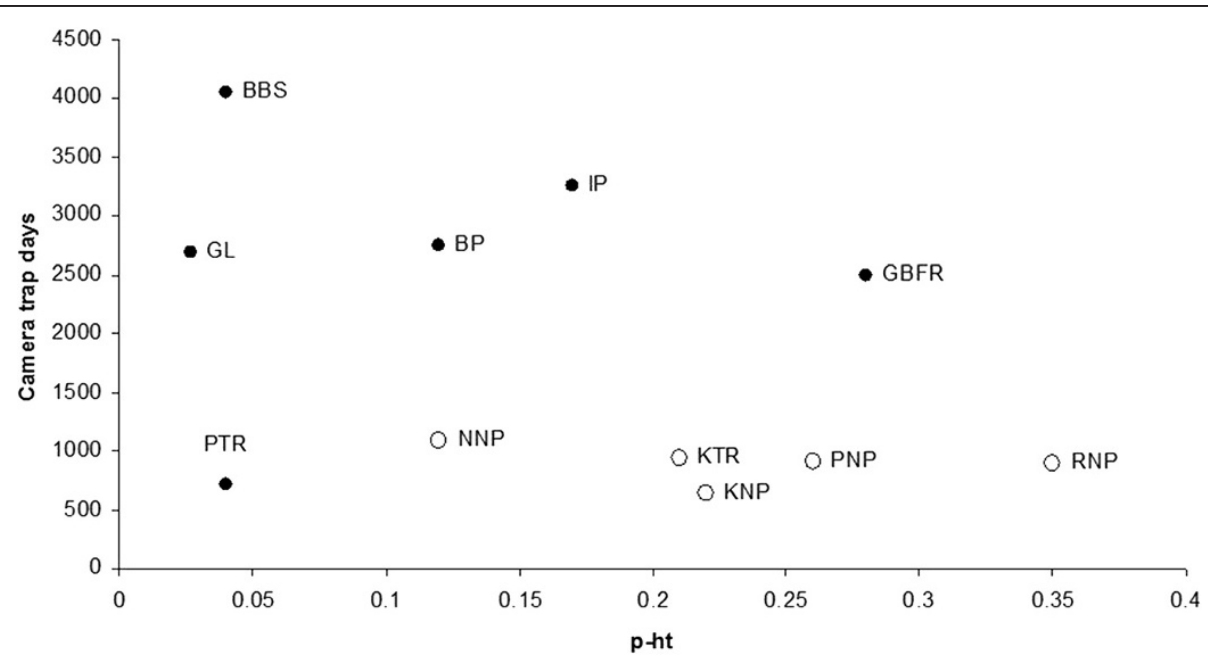

Figure 2 Variation in capture probability (p-ht) in tigers of tropical semi-evergreen forest (dark circle) BBS= Bukit Barisan Selatan, Indonesia; GL = Gunung Leuser, Indonesia; PTR = Pakke Tiger Reserve, India; BP = Bungo Primary selectively logged forest, Sumatra; IP = Ipuh Primary selectively logged forest, Sumatra; GBFR= Gunung Basor Forest Reserve, Malaysia (Source; Carbone et al. 2001) and Peninsular India (open circles) NNP = Nagarhole National Park, India; KTR = Kanha Tiger Reserve, India; KNP = Kaziranga National Park, India; *PNP = Panna National Park, India; RNP = Ranthambhore National Park, India (Source; Karanth and Nichols 1998; *Karanth et al. 2004b). 
hunting. Although hunting has ritual, recreational, and subsistence value (Datta 2002; Hilaluddin et al. 2005; Mishra et al. 2006), it is also increasingly being driven by the high market value for derivatives from species such as tigers. Given the selective logging and hunting reported in tropical rain forests, the low density of species of carnivore including tigers may be adversely affected, leading to local extinction. As tigers have large habitat requirements, the effects of selective logging leading to the fragmentation and isolation of forest reserves, will severely affect the long-term viability of tiger populations across this landscape. Intensive and extensive monitoring of such elusive species that occur at a very low density and with a very low capture probability, require more effort in terms of money and time for monitoring purposes in tropical semi-evergreen forests. Therefore, we suggest a need for regular intensive and extensive monitoring of tiger (i.e., distribution, abundance, population density) and habitat characteristics, which may be undertaken in small forest blocks $\left(100-150 \mathrm{~km}^{2}\right)$ due to lack of easy accessibility of areas to avoid any local extinction in the future. This may be done by using camera trapping with increased capture days or widely used non-invasive genetic sampling (NGS) in carnivores (Mondol et al. 2009). It has also been suggested NGS is a suitable approach in areas, where large carnivores exhibited at low densities (Mondol et al. 2009), and enormous efforts would be needed to achieve reliable estimates (Foster and Harmsen 2012). Our results also demonstrate the need for further research on tiger ecology in tropical rain forests to inform decision makers and conservation planners of the conservation value of such habitats. Because this is one of the first systematic sampling studies in tropical semi evergreen forest of India, our information forms a base for detecting changes in populations in the future. We hope that future research will highlight the role of rain forests for tiger conservation and aid in providing effective tiger management guidelines for sustainable forest management in tropical rain forests.

\section{Competing interests}

The authors declare that no competing interests exist.

\section{Authors' contributions \\ RS, PRK and SPG conceived and designed this study. RS, DSC, and SM performed the field work, collect the field data. RS and DSC analyzed the camera trap data. RS and SPG wrote the manuscript. SPG and PRK provided their inputs for improving the manuscript quality. After reading the final manuscript carefully, all the authors approved it.}

\section{Acknowledgements}

We thank the Director and Dean of the Wildlife Institute of India for their support. We would like to thank the Arunanchal Pradesh Forest Department, park officials and field staff at Pakke Tiger Reserve for permission and facilitating this work. This study was made possible by financial and logistic support from the Wildlife Institute of India (Ministry of the Environment and Forest, Government of India).

\section{Author details}

${ }^{1}$ Wildlife Institute of India, Post Box \# 18, Dehradun, Uttarakhand 248001 , India. ${ }^{2}$ Boone and Crockett Program in Wildlife Conservation, University of Montana, Missoula, MT 59812, USA.

Received: 13 March 2014 Accepted: 22 August 2014

Published: 24 August 2014

\section{References}

Barber-Meyer SM (2010) Dealing with the clandestine nature of wildlife- trade market surveys. Conserv Biol 2:918-923

Carbone C, Christie S, Conforti K, Coulson T, Franklin N, Ginsberg JR, Griffiths M, Holden J, Kawanishi K, Kinnaird M, Laidlaw R, Lynam A, Macdonald DW Martyr D, Mcdougal C, Nath L, O'Brian T, Seidensticker J, Smith DJL, Sunquist M, Tilson R, Wan Shahruddin NW (2001) The use of photographic rates to estimate densities of tiger and other cryptic mammals. Anim Conserv 4:75-79

Champion HG, Seth SK (1968) A Revised Survey Of The Forest Types Of India. Manager Of Publications. Government of India press, New Delhi, p 404

Chapron G, Miquelle DG, Lambert A, Goodrich JM, Legrandre S, Clobert J (2008) The impact on tigers of poaching versus prey depletion. J Appl Ecol 45:1667-1674

Datta A (2002) Status Of Hornbills And Hunting Among Tribal Communities In Eastern Arunachal Pradesh. Report submitted to the Wildlife Conservation Society, New York and WCS- -India Program, Bangalore

Datta A, Goyal SP (1997) Response of Arboreal Mammals to Selective Logging in Arunanchal Pradesh. Final Report, WII, Dehradun

Datta A, Anand MO, Naniwadekar R (2008) Empty forests: Large carnivore and prey abundance in Namdapha National Park, north-east India. Biol Conserv 141:1429-1435

Dinerstein E, Loucks C, Wikramanayake E, Ginsberg J, Sanderson E (2007) The fate of wild tigers. Bioscience 57:508-514

Efford MG (2004) Density estimation in live-trapping studies. Oikos 106:598-610 Efford MG (2008) Density 4.3: Software For Spatially Explicit Capture-Recapture., Available at http://www.otago.ac.nz/density Accessed 15 March 2009

Efford MG (2011) Estimation of population density by spatially explicit capturerecapture analysis of data from area searches. Ecology 92:2202-2207

Eisenberg JF (1980) The Density And Biomass Of Tropical Mammals. In: Soulé M, Wilcox B (eds) Conservation Biology: An Evolutionary-Ecological Perspective. Sinauer Associates, Inc., Publishers, Sunderland, Massachusetts, pp 35-55

Foster RJ, Harmsen BJ (2012) A critique of density estimation from camera-trap data. J Wildl Manag 76:224-236

Glanz WE (1982) Adaptive Zones Of Neotropical Mammals: A Comparison Of Some Temperate And Tropical Patterns. In: Mares MA, Genoways HH (eds) Mammalian Biology in South America: The Pymatuning Symposia in Ecology, Special Publication Series, vol 6, University of Pittsburgh. Linnesville, PA, USA, pp 95-110

Gopalaswamy AM, Royle JA, Delampady M, Nichols JD, Karanth KU, Macdonald DW (2012) Density estimation in tiger populations: combining information for strong inference. Ecology 93(7):1741-1751

Harmsen BJ (2006) The use of camera traps for estimating abundance and studying the ecology of jaguars (Panthera onca). Thesis, University of Southampton, England, United Kingdom

Hilaluddin R, Kaul R, Ghose D (2005) Conservation implications of wild animal biomass extractions in Northeast India. Anim Biodivers Conserv 28:169-179

Jhala YV, Qureshi Q, Gopal R, Sinha PR (2011) Status of the Tigers, Co-predators, and Prey in India. Technical Report. Wildlife Institute of India, Dehradun

Johnsingh AJT, Ramesh K, Qureshi Q, David A, Goyal SP, Rawat GS, Rajapandian K, Prasad S (2004) Conservation Status of Tiger and Associated Species in the Terai Arc Landscape, India. RR-04/001. Wildlife Institute of India, Dehradun

Karanth KU, Nichols JD (1998) Estimation of tiger densities in India using photographic captures and recaptures. Ecology 79:2852-2862

Karanth KU, Nichols JD (2000) Ecological Status and Conservation of Tigers in India. Final Technical Report to the Division of International Conservation, US Fish and Wildlife Service, Washington DC and Wildlife Conservation Society, New York. Centre for Wildlife Studies, Bangalore, India

Karanth KU, Nichols JD (2002) Monitoring Tigers and their Prey: A Manual for Researchers, Managers and Conservationists in Tropical Asia. Centre for Wildlife Studies, Bangalore, India

Karanth KU, Nichols JD, Kumar NS, Link WA, Hines JE (2004) Tigers and their prey: predicting carnivore densities from prey abundance. Proc Natl Acad Sci U S A 101:4854-4858 

of the Indochinese tiger (Panthera tigris corbetti) and other large mammals in a forest complex in northeastern Thailand. Natural History Bull Siam Soc 49:61-75

Lynam AJ, Khaing ST, Zaw KM (2006) Developing a national tiger action plan for the Union of Myanmar. Environ Manage 37:30-39

Lynam AJ, Rabinowitz A, Myint T, Maung M, Latt KT, Po SHT (2009) Estimating abundance with sparse data: tigers in northern Myanmar. Popul Ecol 51:115-121

Mishra C, Madhusudan MD, Datta A (2006) Mammals of the high altitudes of western Arunachal Pradesh, Eastern Himalaya: an assessment of threats and conservation needs. Oryx 40:29-35

Mondol S, Karanth KU, Kumar NS, Gopalaswamy AM, Andheria A, Ramakrishnan U (2009) Evaluation of non-invasive genetic sampling methods for estimating tiger population size. Biol Conserv 142:2350-2360

Myers N, Mittermeier RA, Miittermeier CA, Da Fonseca GAB, Kent J (2000) Biodiversity hotspots for conservation priorities. Nature 403:853-858

Nowell K, Jackson P (1996) Wild Cats: Status Survey and Conservation Action Plan. IUCN, Gland, Switzerland

Otis DL, Burnham KP, White GC, Anderson DR (1978) Statistical inference from capture data on closed animal populations. Wildlife Monograph 62:1-135

Ramesh T, Sridharan N, Sankar K, Qureshi Q, Selvan KM, Gokulakkannan N, Francis P, Narasimmarajan K, Jhala W, Gopal R (2012) Status of large carnivores and their prey in tropical rainforests of South-western Ghats, India. Trop Ecol 53(2):137-148

Reddy VG (2008) Lessons from two local extinctions: Sariska and Kailadevi (Ranthambhore) in Rajasthan, India. Conserv Soc 6:256-262

Rexstad EA, Burnham KP (1991) User's Guide for Interactive Program CAPTURE. Colorado Cooperative Wildlife Research Unit. Colorado State University, Fort Collins, USA

Royle JA, Karanth KU, Gopalaswamy AM, Kumar NS (2009) Bayesian inference in camera trapping studies for a class of spatial capture-recapture models. Ecology 90(11):3233-3244

Singh R, Mazumdar A, Sankar K, Qureshi Q, Goyal SP, Nigam P (2013a) Interbirth interval and litter size of free-ranging Bengal tiger (Panthera tigris tigris) in dry tropical deciduous forests of India. Eur J Wildl Res 59:629-636

Singh R, Qureshi Q, Sankar K, Krausman PR, Goyal SP (2013b) Use of camera traps to determine dispersal of tigers in semi-arid landscape, western India. J Arid Environ 98:105-108

Singh R, Qureshi Q, Sankar K, Krausman PR, Goyal SP (2014a) Female reproductive characteristics of Bengal tigers, Ranthambhore Tiger Reserve, India. Eur J Wild Res 60(4):579-587

Singh R, Qureshi Q, Sankar K, Krausman PR, Goyal SP, Nicolson KL (2014b) Population density of striped hyenas in relation to habitat in a semi-arid landscape, western India. Acta Theriol, DOl:10.1007/s13364-014-0187-8

Sunquist ME, Karanth KU, Sunquist FC (1999) Ecology behaviour and resilience of the tiger and its conservation needs. In: Seidensticker J, Christie S, Jackson P (eds) Riding the Tiger: Tiger Conservation in Human-dominated Landscapes, Cambridge University Press, Cambridge, pp 5-18

Zimmermann F, Breitenmoser-Würsten C, Molinari-Jobin A, Breitenmoser U (2013) Optimizing the size of the area surveyed for monitoring a Eurasian lynx (Lynx lynx) population in the Swiss Alps by means of photographic capture-recapture. Integ Zool 8(3):232-43

doi:10.1186/2193-1801-3-462

Cite this article as: Singh et al:: Tiger density in a tropical lowland forest in the Eastern Himalayan Mountains. SpringerPlus 2014 3:462.

\section{Submit your manuscript to a SpringerOpen ${ }^{\circ}$ journal and benefit from:}

- Convenient online submission

- Rigorous peer review

- Immediate publication on acceptance

- Open access: articles freely available online

- High visibility within the field

- Retaining the copyright to your article

Submit your next manuscript at $\gg$ springeropen.com 